\title{
Testate amoebae analysis in ecological and paleoecological studies of wetlands: past, present and future
}

\author{
Edward A. D. Mitchell • Daniel J. Charman • \\ Barry G. Warner
}

Received: 21 August 2007 / Accepted: 21 August 2007 / Published online: 30 October 2007

(C) Springer Science+Business Media B.V. 2007

\begin{abstract}
Testate amoebae are an abundant and diverse polyphyletic group of shelled protozoa living in aquatic to moist habitats ranging from estuaries to lakes, rivers, wetlands, soils, litter, and moss habitats. Owing to the preservation of shells in sediments, testate amoebae are useful proxy indicators complementary to long-established indicators such as pollen and spores or macrofossils. Their primary use to date has been for inferring past moisture conditions and climate in ombrotrophic peatlands and, to a lesser extent, to infer $\mathrm{pH}$ in peatlands and the trophic or nutrient status of lakes. Recent research on these organisms suggests other possible uses in paleoecology and ecology such as sea-level reconstruction in estuarine environments, as indicators of soil or air pollution, and monitoring recovery of peatland. We review the past and present use of testate amoebae, the challenges in current research, and provide some ideas on future research directions.
\end{abstract}

Keywords Testate amoebae $\cdot$ Protozoa $\cdot$ Peatland $\cdot$ Sphagnum $\cdot$ Paleoecology $\cdot$ Bioindicators $\cdot$ Community ecology $\cdot$ Transfer functions $\cdot$ Peatland management · Restoration ecology

E. A. D. Mitchell ( ()

Swiss Federal Research Institute WSL, Wetlands Research Group, Station 2, Lausanne CH-1015, Switzerland

e-mail: edward.mitchell@wsl.ch

E. A. D. Mitchell

EPFL, Laboratoire des Systèmes Écologiques (ECOS), Station 2, Lausanne CH-1015, Switzerland

D. J. Charman

School of Geography, University of Plymouth, Plymouth, Devon PL4 8AA, UK

B. G. Warner

Department of Earth and Environmental Sciences, University of Waterloo, Waterloo,

ON, Canada, N2L 3G1 


\section{Introduction}

Testate amoebae are unicellular protists, which are ubiquitous in environments such as lakes, rivers, mosses, and soils, but also occur in estuarine environments (Meisterfeld 2002a, b). They are small (mostly 20-200 $\mu \mathrm{m}$-roughly the size of pollen grains), abundant (e.g., $10^{3}-10^{4}$ individuals $\mathrm{g}^{-1}$ dry weight peat), and diverse (about 2000 species described so far, and usually between 10 and 30 species in any given sample). Testate amoebae build a test (shell) either from proteinaceous, calcareous, or siliceous material. Some of them form agglutinated tests by gluing together organic or mineral particles from their surrounding environment. These tests cover a relatively broad range of sizes (over one order of magnitude) and a high diversity of morphologies (Fig. 1), which allows identification to species level. These tests are usually well preserved in peat and lake sediments (Warner 1990).

Testate amoebae have a long fossil history, with fossils dated from the Cretaceous (Boeuf and Gilbert 1997; Foissner and Schiller 2001; Patterson and Kumar 2002; Schmidt et al. 2001; Schönborn et al. 1999), the Carboniferous (Loeblich and Tappan 1964), and perhaps even Late Neoproterozoic (Porter and Knoll 2000). Despite this long fossil history, most paleontological studies of testate amoebae focus on the Quaternary and especially on the Holocene where they are used as paleobioindicators in lakes and peatlands (Charman 2001; Medioli et al. 1990; Tolonen 1986).
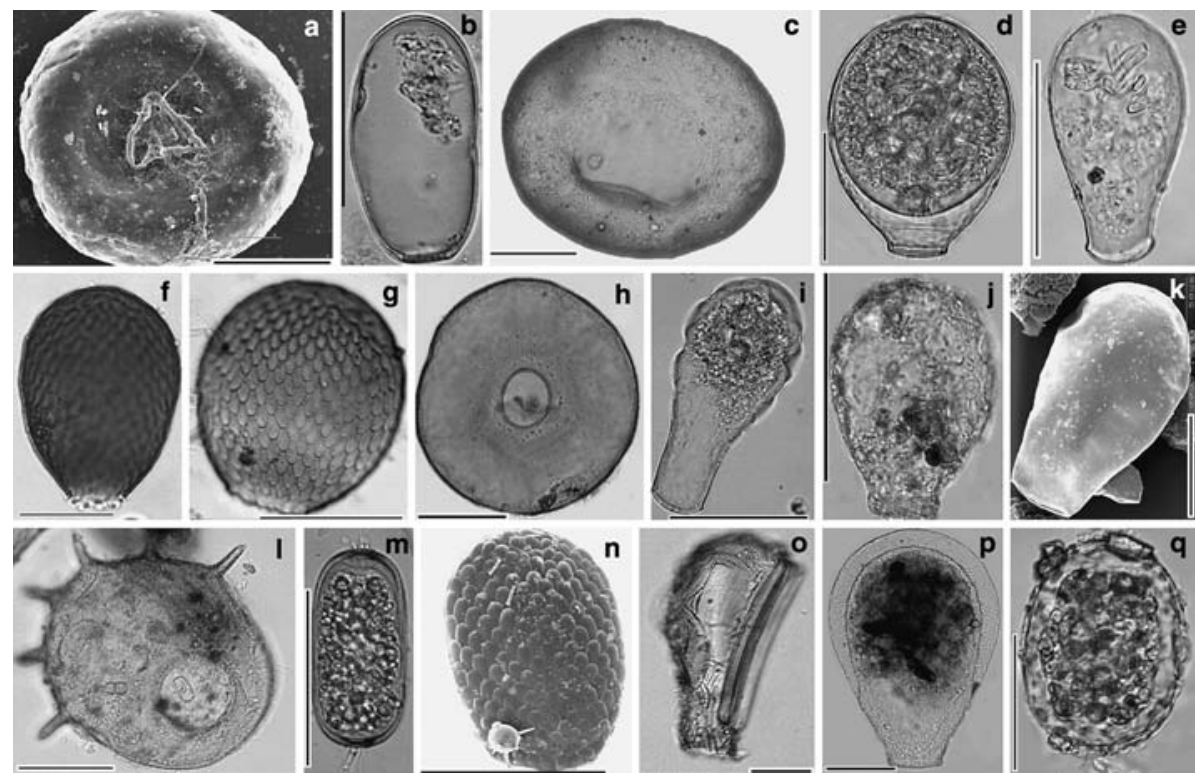

Fig. 1 Light- and scanning electron micrographs of some testate amoebae found in peatlands, illustrating the range of morphological variability; (a) Trigonopyxis arcula, (b) Hyalosphenia subflava, (c) Bullinularia indica, (d) Nebela tincta, (e) Nebela militaris, (f) Assulina muscorum, (g) Assulina seminulum, (h) Arcella artocrea, (i) H. elegans, (j) Physochila griseola, (k) H. papilio, (1) Centropyxis aculeata, (m) Archerella flavum, (n) Placocista spinosa var. hyalina, (o) Difflugia bacillifera, (p) N. carinata, (q) Amphitrema wrightianum. Scale bars indicate approximately $50 \mu \mathrm{m}$ except for A. muscorum: $20 \mu \mathrm{m}$. SEM were conducted at the University of Alaska Anchorage by K. Kishaba, J. Kudenov and E. Mitchell 
In this review, we cover selected aspects of the phylogeny, taxonomy, biogeography, biology and ecology of testate amoebae. We then discuss the application of this knowledge to paleoecological research and present some new fields of research and application. This review also constitutes a guide to an extensive selection of the literature on testate amoebae.

\title{
Testate amoeba taxonomy and biogeography: facts and open questions
}

\author{
Higher taxonomic levels: phylogeny
}

Testate amoebae are a polyphyletic assemblage of at least two major, unrelated taxonomic groups of mostly heterotrophic unicellular eukaryotes (Meisterfeld 2002a, b; Wylezich et al. 2002). Testate amoebae have been divided based on pseudopod morphology. The first group has lobose pseudopodia (order Arcellinida). The second group with filose pseudopodia is represented mainly by order Euglyphida. Some testate amoebae possessing anastomosing networks of reticulopodia, and traditionally classified in the phylum Granuloreticulosea (Bovee 1985), have recently been placed among testate amoebae with filose pseudopodia (Meisterfeld 2002b). The phylogenetic position of Arcellinida and Euglyphida, among Amoebozoa and Cercozoa, respectively, has been established based on ribosomal DNA sequences (Cavalier-Smith and Chao 1997; Meisterfeld 2002a, b; Nikolaev et al. 2005; Wylezich et al. 2002). However, DNA sequences are available only for a small number of taxa and therefore the higher-level taxonomy of both orders still rests entirely on morphological characters. It is urgent to complete the sequence data for all families and genera, in order to establish a solid phylogeny based on molecular and morphological characters.

Perhaps because of the uncertainty about their phylogeny, many different names have been used to describe these organisms: thecamoebians, rhizopods, testate amoebae, testaceans, and arcellaceans. Some of these names implicitly suggest a taxonomic affiliation. For example, the term arcellaceans implies relationships to the order Arcellinida or the genus Arcella, which is incomplete and unrepresentative of all testate amoebae. Rhizopods on the other hand are not restricted to testate amoebae and may include naked amoebae. We suggest that the terms testaceans or testate amoebae should be preferred as they are unambiguous.

Lower taxonomic levels: genera and species

The taxonomy of testate amoebae at lower taxonomic levels is largely based on shell morphology and is also unresolved (Lee et al. 2000; Patterson 1996). Although uncertainties at the higher taxonomic levels have little impact on the usefulness of testate amoebae in ecological and paleoecological research, the establishment of solid phylogenetic relationships is necessary for determining the taxonomic significance of some important morphological features that are used to identify the species.

Despite the fact that the common species can usually be identified with confidence, there is an urgent need for taxonomic revision and a synthesis of the existing data. There are no recent updated complete monographs or even species lists and many of the approximately 2000 described species are probably never securely identified by most ecologists for lack of appropriate identification criteria, the difficulty in accessing the original descriptions, or simply because no up to date synthesis exists in which the identification characteristics of 
all species are clearly described. The identification of species is usually based on monographs, which often date back to decades or even over a century and which, despite the fact that none of them includes all the described species, are still the most useful resources (Cash and Wailes 1915; Chardez 1969, 1991; Corbet 1973; Deflandre 1928, 1929, 1936; Grospietsch 1958, 1964; Harnisch 1958; Ogden 1983; Ogden and Hedley 1980; Penard 1902; Schönborn 1965b). A few more recent studies provided clarifications on some selected taxa (Foissner and Korganova 1995, 2000; Lüftenegger et al. 1988; Schönborn et al. 1983). A valuable guide for paleoecologists was recently published by the Quaternary Research Association (Charman et al. 2000). However, much remains to be done to make the identification of testate amoebae more straightforward for ecologists and paleoecologists, and through this, the comparison among studies more reliable. The amount of work involved in such a task is huge and will require a significant investment.

Moreover, the intra-specific variability of test morphology in most taxa has not yet been satisfactorily assessed. It is quite likely that many species have been described based on the extremes of a continuum of morphotypes of the same variable species (Bobrov and Mazei 2004). Recent studies show that (1) abiotic and biotic environmental factors such as food source, temperature, and insecticides affect the shell morphology (Chardez 1989; Schönborn 1992a; Wanner 1999; Wanner et al. 1994; Wanner and Meisterfeld 1994), and (2) testate amoebae are characterized by a high degree of morphological variability both among and within populations (Bobrov and Mazei 2004), and (3) even under controlled conditions, the morphological variability of the shell increases with time (Schönborn 1992a). Such variability is apparently at least partly genetically determined and allows the species to adapt to the spatial or temporal heterogeneity of their environment (Bobrov and Mazei 2004).

Phenotypic plasticity may however not necessarily mean that testate amoebae are less useful as a tool for ecologists and paleoecologists. Indeed if the relationships between environmental conditions and shell morphology were well understood and could be reliably predicted, then this information could be used to infer environmental conditions on the basis not only of community composition but also of shell morphological characteristics. Instead of having discrete categories (species) along a gradient, ecologists and paleoecologists would have a continuum. Inference (forecasting) models could then be built from the analysis of such continua, with linear or polynomial regression. We therefore call for more detailed morphometric analyses of (1) living taxa under known environmental conditions, and (2) cultures grown under controlled conditions. This approach will enable a predictive model of morphological characteristics as a function of environmental conditions to be created. Such a model would have direct applications for paleoenvironmental reconstructions.

The fact that testate amoebae have been found to be useful despite these imperfections suggests that they could become an even better tool for ecologists if the taxonomy was improved. The present state of testate amoebae taxonomy and the above-mentioned findings call for (1) a conservative approach to the description of new species and (2) a test of the morphology-based taxonomy using molecular data (e.g., phylogenetic trees derived from ribosomal RNA sequences) with the long-term goal of revising the taxonomy of testate amoebae based on the combination of molecular and morphological data. We suggest a combined approach focusing on the morphology, molecular taxonomy, and ecology of problematic groups of species such as the genera Difflugia, Centropyxis, Phryganella, Trinema, and Euglypha or groups of species within otherwise "easy" genera such as the Nebela tincta species complex. 

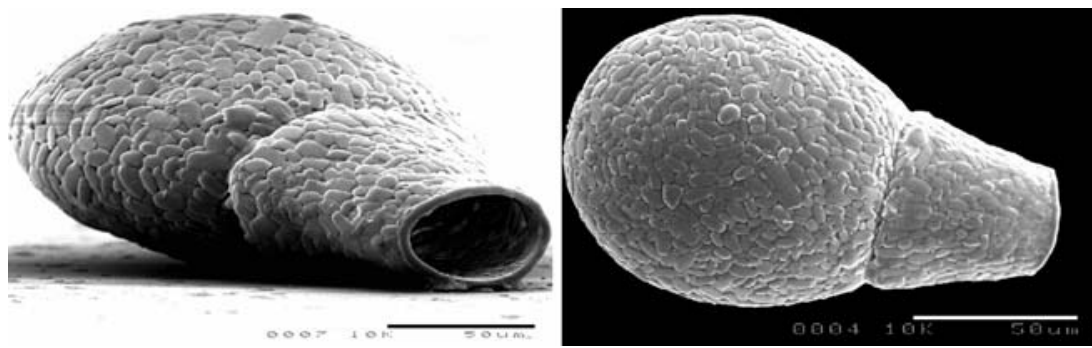

Fig. 2 Apodera vas (Certes), a testate amoeba found in South and Central America and Sub-Sahara Africa but lacking from North America and Eurasia. This individual is from a Sphagnum moss collected in Tanzania. SEM conducted at the University of Alaska Anchorage by K. Kishaba, J. Kudenov and E. Mitchell

The debate over cosmopolitanism

The question of the cosmopolitanism of microorganisms is of great importance to the global use of testate amoebae as bioindicators and paleobioindicators in peatland. There is currently a lively debate as to whether free-living protists are ubiquitous (Finlay 2002; Finlay and Clarke 1999; Finlay et al. 2001; Finlay et al. 1999; Finlay and Fenchel 1999) or whether some, and perhaps indeed most, of them have limited geographical distributions (Foissner 1997a, 1998, 1999). Testate amoebae represent an interesting paradox as they provide evidence for both views. Indeed, the available data suggests that they include both species small enough to be transported passively over long distances and species large enough for this to be impossible (Wilkinson 1994; Wilkinson 2001). An often-cited example of the latter is Apodera (Nebela) vas (Fig. 2), a species that has so far been found mostly in the Southern Hemisphere, with some Northern Hemosphere records in Hawaii, Venezuela, and Central America, but no records from Eurasia or North America (Deflandre 1936; Van Oye 1944). Given the large size of this species $(130-210 \mu \mathrm{m})$, its distinct morphological characteristics, and the larger number of studies on testate amoebae of the Northern Hemisphere as compared to the Southern Hemisphere, it is very unlikely that it would have been overlooked.

Excessive splitting of taxa may also give the impression of a higher rate of endemism than actually exists. Given the variability of shell morphology discussed above, we believe that many of the described species and even more of the subspecies and varieties should not be used as evidence for limited distribution ranges as many of them were not confirmed or observed by anyone else than the person who first described them. On the other hand, the existing literature on testate amoebae biogeography is mostly based on the observation of morphotypes. It remains possible that a given morphological species may in fact hide several genetically distinct species (i.e. cryptic species) that may differ with respect to geographical distributions and/or ecological requirements. In a different context, cryptic species of both benthic and planktonic foraminifera have recently been discovered, some of which have cosmopolitan distribution while others have not (Darling et al. 2004; Darling et al. 2000; Hayward et al. 2004).

In addition to size, there might also be a difference in the cosmopolitanism of species depending on their habitat: wetland species and species living in the soil litter and mosses are more likely to be transported over long distances than species living deeper in the soil. Clearly the debate on cosmopolitan distribution versus local endemism is unlikely to be resolved unless the size range and habitat are specified. Even so, the possible existence of 
cryptic species calls for caution and further studies of global and local distribution patterns, ideally with an approach combining morphological, ecological, and molecular methods such as ribosomal RNA sequencing (Mitchell and Meisterfeld 2005).

\section{Biology}

A review of the present knowledge of the biology of testate amoebae is beyond the scope of this paper. Much remains unknown about their life, for example the relative importance of asexual and sexual reproduction (Mignot and Raikov 1992), and their physiology. In the following paragraphs we will focus only on two aspects that are most relevant to the ecologist: their shell characteristics and their general role in the ecosystem.

\section{Source of material for test construction}

Testate amoebae need to find the required material to build their test and this requirement may be one of the constraints that determine the micro-distribution of species (Meisterfeld 1977; Schönborn 1963). An example of niche separation between two closely related taxa can be seen in the vertical micro-distribution of Amphitrema wrightianum and A. flavum. Both species may both be found in wet and oligotrophic conditions such as pools in the centre of raised bogs, with A. flavum usually with its optima in slightly drier conditions than A. wrightianum. A. flavum produces a shell that is entirely composed of proteinaceous material whereas $A$. wrightianum uses xenosomes (usually minute organic debris) and cements them together to create a test. This difference in shell construction may prevent $A$. wrightianum from fully colonizing the uppermost part of Sphagnum mosses (the capitulum) because there may not be enough free organic or mineral material for shell construction. A further example of this kind is the occurrence of a number of taxa of the genus Difflugia (e.g., D. bacillifera, D. elegans, D. leydyi) in very wet conditions on oligotrophic peatlands. The tests of this genus are also xenosomic and it is likely that the silica particles predominantly used in the tests are more abundant in shallow pools. These constraints may also explain some of the patterns of species distribution along micro-environmental gradients, which are usually interpreted as representing responses to variables such as $\mathrm{pH}$ or moisture that are more easily measured than the availability of xenosomes for shell construction.

Functional role of testate amoebae

Testate amoebae are usually considered to be predators of bacteria and fungi (Hausmann et al. 2003). As such they play an important role in the cycling of nutrients in soil, although clearly flagellates, naked amoebae and/or ciliates are probably more important, at least in mineral soils (Clarholm 1981, 1985, 2002; Clarhom and Rosswall 1980; Coûteaux and Pussard 1983; Schönborn 1992b). However, despite the fact that there are few data on the functional role of testate amoebae in peatlands, the observation that they are by far the dominant group of protozoa in Sphagnum suggests that in these ecosystems they play a significant role (Gilbert et al. 1998a; Gilbert et al. b). In support of this idea, peatland testate amoebae have also been found to use a wide variety of food sources including other protists, fungi, organic matter and micro-metazoa such as rotifera (Gilbert et al. 2000). Despite this general knowledge, it is striking that we still do not have a good idea about the exact trophic role of most soil protozoa, even of the dominant species. 
Environmental influences on testate amoebae include many potential direct and indirect effects. Environmental conditions, such as rising atmospheric $\mathrm{CO}_{2}$ concentrations, global warming, increased nitrogen deposition, drainage, or changes in rainfall patterns may affect soil protozoa directly and, perhaps more importantly, also indirectly through their effect on the vegetation and prey organisms (Gilbert et al. 1998a, b; Lussenhop et al. 1998; Mitchell 2004; Mitchell et al. 2003; Treonis and Lussenhop 1997).

\section{Ecology and paleoecology}

Community structure and responses to ecological gradients

The responses of testate amoebae to the major ecological gradients in peatlands, such as the fen-bog transition and the humidity gradient, have long been established (Harnisch 1925, 1927; Heal 1961, 1962, 1964; Schönborn 1962). Later work has provided a more quantitative understanding of these relationships and tested them over a larger geographical range. The earliest ecological classification of peatland testate amoebae is the eight-class wetness scale of Jung (1936). More recently, multivariate classifications of communities (Meisterfeld 1978, 1979; Mitchell et al. 1999; Tolonen et al. 1994) and quantitative relationships between community structure and specific environmental variables have been explored using univariate and multivariate statistics (Bobrov et al. 1999; Booth 2001; Charman 1997; Charman and Warner 1992, 1997; Lamentowicz and Mitchell 2005; Mitchell et al. 2000b; Mitchell et al. 1999). These studies generally show that testate amoebae respond primarily to some measure of moisture (usually either the moisture content of the sample or the water table depth). Seasonal changes in soil moisture content appear to influence shifts in abundance and community composition (Heal 1964; Quinn 2003; Warner et al. 2007). Significant relationships have also been found with $\mathrm{pH}$ and macro-nutrients when a significant range of variability has been sampled (Tolonen et al. 1992). However, in general, the relationship with $\mathrm{pH}$ is secondary to that of hydrology (Booth 2001).

It is also important to emphasise that these empirical relationships do not necessarily reflect the causes of species responses and are not yet based on a thorough physiological understanding of testate amoebae. Indirect effects such as materials for test construction (see above) may be important, but processes related more directly to hydrology can be suggested. For example, higher soil moisture may allow species with larger tests to successfully reproduce because of the thicker water films on plant surfaces (e.g. Assulina seminulum vs A. muscorum; Nebela tincta var. major vs. N. militaris). In addition to size, shape is important: Thin tests may be better suited to life in the thin water films under drier conditions (e.g., flattened Arcella species such as A. arenaria versus rounder ones such as A. gibbosa). The spines on the surface of some taxa may be an adaptation to limit movement in very wet conditions and where similar spined and glabrous taxa occur, the former mostly occupies wetter niches (e.g., Euglypha ciliata and E. ciliata var. glabra, Placocista spinosa and P. spinosa var. hyalina) (Bobrov et al. 1999). Further work on the ecological and physiological mechanisms underlying the recorded gradients is required to fully understand why testate amoebae communities vary in response to the key variables of hydrology and water chemistry.

Comparisons among different areas of the world reveal that many taxa have very similar water table depth optima but that others (e.g., Centropyxis aculeata, Hyalosphenia papilio, H. elegans, Cyclopyxis arcelloides, Nebela tincta, $H$. subflava) vary in their relative position on the hydrological gradient (Fig. 3). Such comparative results can however be 


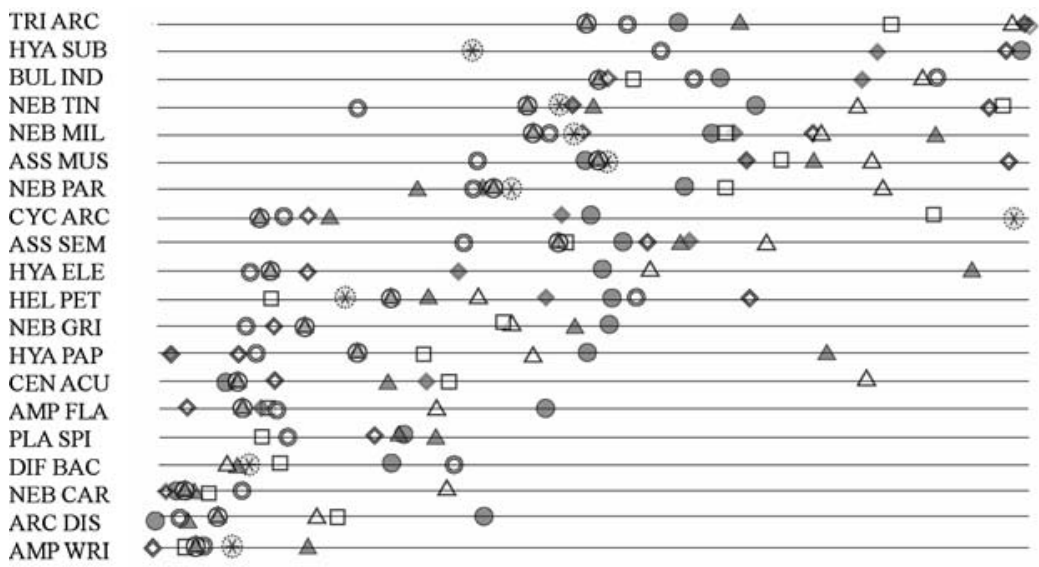

Moist

Optimum water-table depth

Dry

\begin{tabular}{|c|c|c|}
\hline$-1 \mathrm{~cm}$ & Upper Michigan (Booth2001) & $31 \mathrm{~cm}$ \\
\hline $9 \mathrm{~cm}$ & $\diamond$ NW Ontario/Minnesota (Warner \& Charman 1994) & $58 \mathrm{~cm}$ \\
\hline $0 \mathrm{~cm}$ & $\triangle$ Newfoundland (Charman \& Warner 1997) ${ }^{1}$ & $23 \mathrm{~cm}$ \\
\hline $0 \mathrm{~cm}$ & $\square$ Finland (Tolonen et. al 1992) ${ }^{2}$ & $23 \mathrm{~cm}$ \\
\hline $3 \mathrm{~cm}$ & Great Britain (Woodland et al. 1998) ${ }^{3}$ & $12 \mathrm{~cm}$ \\
\hline $9 \mathrm{~cm}$ & $\diamond$ Switzerland and France (Mitchell et al. 1998) & $60 \mathrm{~cm}$ \\
\hline$-5 \mathrm{~cm}$ & $\triangle$ Russia (Bobrov et al 1999) ${ }^{1}$ & $31 \mathrm{~cm}$ \\
\hline $3 \mathrm{~cm}$ & * New Zealand (Charman 1997) ${ }^{1}$ & $37 \mathrm{~cm}$ \\
\hline$-3 \mathrm{~cm}$ & (2) Poland- this study ${ }^{1}$ & $55 \mathrm{~cm}$ \\
\hline
\end{tabular}

Fig. 3 Water table depth optima of testate amoebae in Sphagnum peatlands: a summary of studies from Europe, North America and New Zealand, modified from Booth (2001), with kind permission from the Journal Wetlands

strongly biased by (1) the range of hydrological conditions sampled, (2) the way the water table was measured (e.g., single point measurement or long-term average), and (3) the taxonomic resolution (see above). The only way to truly ascertain that testate amoebae indeed have similar responses to ecological gradients in different regions is to carry out a multi-site study with a standard protocol, from sampling strategy to numerical analyses. This has not been done to date. This question also relates to two other fundamental questions: (1) the supposed cosmopolitanism of testate amoebae (see above), and (2) the possible response of testate amoebae to climate (see below). If testate amoebae are not truly cosmopolitan, or if they respond to temperature in addition to responding to moisture and $\mathrm{pH}$, then it may be possible that the ecological preferences of a given morphological species is not identical in different geographical areas. If true this could also mean that the ecological preferences of species could have change over time, perhaps even within the Holocene.

Within each community or microhabitat type there are more subtle differences in faunas such as changes in the relative abundance of species. For example, the micro-distribution of testate amoebae along Sphagnum stems suggests that they are highly sensitive to vertical micro-environmental gradients (e.g., light, moisture) (Bonnet 1958; Booth 2002; Chacharonis 1954, 1956; Heal 1962, 1964; Meisterfeld 1977; Mitchell and Gilbert 2004; Schönborn 1963). Furthermore, even in an apparently homogeneous surface such as an almost flat, 


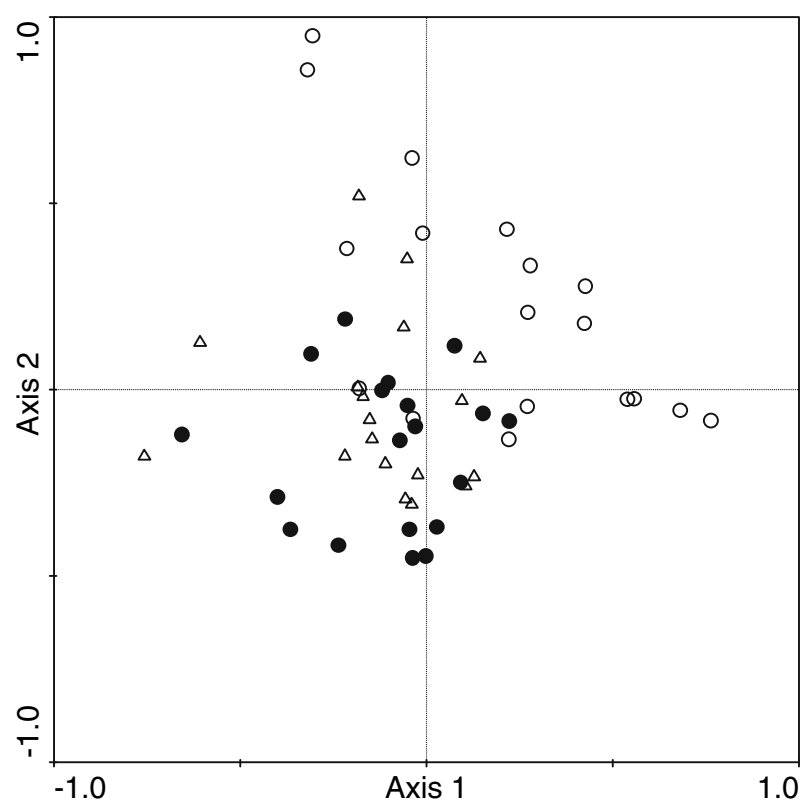

Fig. 4 Sample plot of canonical correspondence analysis (CCA) of testate amoebae data in an open peatland area. The study site is a small "schwingmoor" peatland complex dominated by Sphagnum in southern Ontario, Canada. The site is dominated by Chamaedaphne calyculata and Vaccinium oxycoccus with hummocks of S. fuscum and S. capillifolium, and lawns of S. magellanicum, and hollows of S. cuspidatum. Samples of Sphagnum were collected for testate amoebae analysis. Species data were log-transformed, and rare species were down-weighted. Empty circle: spring; filled circle: summer; triangle: fall (October). Warner et al. (2007)

monospecific Sphagnum lawn, complex patterns of community structure can be observed. Using geostatistical tools, such patterns may be explained by the heterogeneity of the environment such as the micro-topography (e.g. maximum vertical difference of $6 \mathrm{~cm}$ within a $40 \times 60 \mathrm{~cm}$ area) and associated small differences in moisture conditions and water chemistry (Mitchell et al. 2000a).

Questions remain surrounding the degree to which seasonal changes and microsite spatial patterns in faunal abundances and composition are controlled by biological influences on the animals themselves or by environmental factors or both. In a recent study, Warner et al. (2007) collected Sphagnum from various microhabitats an open peatland for seasonal comparisons of testate amoebae faunas. A moderate shift in testate amoebae community composition is observed in spring compared to summer and fall faunas (Fig. 4). These changes may be due to moisture fluctuations, or to differences in seasonal dynamics among testate amoebae species.

Much of the work to date has focussed on testate amoebae in Sphagnum-dominated peatlands, primarily in the northern hemisphere. Very little is known about testate amoebae faunas in other types of peatlands, especially in tropical and subtropical latitudes. For example, testate amoebae have been found in peat cores from herbaceous "popales" peatlands in tropical central Mexico (Primeau 2004). Similarly, testate amoebae have been found in the isolated high-altitude "bofedales" Juncaceae-dominated peatlands in the central Andes of South America (Earle 2000; Warner unpublished). Much remains to be learned about the ecology and paleoecology of testate amoebae in the lesser-known 
peatlands in other geographic regions of the world. Perhaps some light could be shed on the evolutionary and biogeographic questions discussed above and help assess the reliability of testate amoebae-derived transfer functions over broad geographical areas and using that as a substitute for time, the long-term stability of these models.

Transfer functions using testate amoebae in peatland paleoecology

The development of large ecological data sets relating testate amoebae to major ecological gradients has led to the development of transfer functions used in paleoecology. Transfer functions describe the relationship between species and an environmental variable of interest (e.g., depth to water table) statistically, and then apply this relationship to fossil assemblages to provide estimates of changes in the environmental parameter through time. Several characteristics make testate amoebae especially useful in paleoecological studies: (1) the tests of many taxa of testate amoebae are well preserved in a variety of lacustrine and terrestrial organic sediments, (2) they are abundant and diverse (Warner 1987), (3) they respond quickly to environmental changes (Buttler et al. 1996), (4) they provide information about the exact coring location (as opposed to e.g. pollen and spores), and (5) they may not respond to exactly the same factors as other indicators such as vascular plants (Mitchell et al. 2000b) and thus provide an independent line of evidence for multi-proxy paleoecological reconstructions (Schreve and Thomas 2001). The growing number of paleoecological studies that have used testate amoebae now attest to the value of the transfer function approach to palaeoenvironmental reconstruction (Beyens and Chardez 1987; Charman 2001; Charman et al. 2001; Charman and Hendon 2000; Charman et al. 1999; Charman et al. 1998; Mitchell et al. 1999; Warner and Charman 1994; Warner and Chmielewski 1992; Woodland et al. 1998). Testate amoebae are also central to an EU-funded research project (ACCROTELM), which aims to provide data on mid-late Holocene climate changes by analysing testate amoebae in peat sediments.

The robustness of any transfer function approach depends partly on the availability of good quality modern data sets but also on an assumption that the species-environment relationship has been stable through time. It is impossible to verify that the ecology of the species has remained constant through time, which is one of the basic assumptions of paleoecology. But it is possible to assess if species-environment relationships are similar across broad geographical areas. The rationale for this approach is that if testate amoebae were able to adapt to local conditions relatively rapidly, it would then be possible to detect differences in their ecological optima among study sites. As noted above, when this is done, the ecological preferences of most species generally compare quite well even between widely spaced sample regions (Booth 2001; Lamentowicz and Mitchell 2005), and this provides a good basis for the application of transfer functions over at least recent geological time periods. But there are also exceptions and these call for further studies.

Another possible limitation of testate amoeba analysis is the lack of modern analogues to some past communities. One such example has recently been stressed for a community strongly dominated by Hyalosphenia subflava and Difflugia pulex (Caseldine and Gearey 2005). It remains to be established is such lack of modern analogues are real or if they perhaps reflect an incomplete sampling for the development of transfer functions. It is indeed possible that such communities represent very degraded situations that could be avoided, consciously or not, when collecting surface samples. For example, Hyalosphenia subflava was found to be associated with forested peatlands in Ontario (Charman and Warner 1992), while it was characteristic for drained peatlands in Finland (Tolonen et al. 1994). The case of Difflugia pulex is more complex as this species has not been found to 
dominate any surface sample to this date. Perhaps we should aim specifically for unusual habitats within peatlands to find communities such as the above-mentioned one?

In ombrotrophic peatlands, the moisture content of the Sphagnum mosses and the depth to the water table are directly linked to climate, and more specifically to the balance between evaporation and precipitation (direct responses to temperature are treated further). The response of testate amoebae to moisture in these ecosystems therefore makes them good indicators of paleoclimate and this is how reconstructed water table depths are now often being interpreted (Charman et al. 2004; Chiverrell 2001; Hendon and Charman 2004; Hendon et al. 2001; Langdon et al. 2003; Mauquoy and Barber 1999, 2002; McGlone and Wilmshurst 1999; Wilmshurst et al. 2002). In these cases, modelling the relationship between testate amoebae and hydrology is only one part of the process. The reconstructions that can be obtained using this approach have been tested against other hydrological proxies such as plant macrofossils and peat humification (Blundell and Barber 2005; Booth and Jackson 2003; Booth et al. 2004; Charman et al. 2001; Charman et al. 1999; Lavoie and Richard 2000; Mauquoy and Barber 2002; McGlone and Wilmshurst 1999; McMullen et al. 2004; Mitchell et al. 2001; Wilmshurst et al. 2002). Blundell and Barber (2005) concluded that testate amoebae provided more consistently reliable reconstructions that the other techniques, but that a multi-proxy approach is nevertheless preferable. The accuracy of reconstructions that can be obtained can also be demonstrated by comparisons with instrumental records of water table change and climate variability over the relatively recent past (Charman et al. 2004). This study showed that even the relatively low amplitude changes in water table that have occurred over the past 50-200 years can be reconstructed with some confidence using a transfer function approach. The root mean squared error of prediction for the transfer function used in this study (Woodland et al. 1998) was only $3.5 \mathrm{~cm}$.

The degree of preservation of subfossil testate amoebae in peat or other sediments can be quite variable and may depend on both the condition under which the sediment was produced and its subsequent history. A major gap exists in our understanding of taphonomic processes associated with transformation of living plant to peat, and hence transformation of living testate amoebae faunas to dead faunal assemblages. If we consider that Sphagnum plants and litter generally lose integrity and mass rapidly immediately upon senescence and early stages of decomposition compared to later stages, and how Sphagnum litter travels through the oxic layer before entering the deeper anoxic layers, how might such processes and length of time shape dead testate amoebae communities? Is it possible that dead fossil assemblages are mixed assemblages that originated from different microhabitats? In order to provide answers to such questions, more attention should be devoted testate amoeba taphonomy; it could indeed become a discrete field of study in itself.

\section{Future applications of testate amoebae}

The short generation time and wide distribution (albeit with reservations in mind regarding cosmopolitanism) of testate amoebae makes them good indicators for the monitoring of environmental change. Their usefulness as bioindicators is not restricted to long-term hydrological development of Sphagnum peatlands. Although a large proportion of the work on peatland ecology has focused on the reconstruction of former hydrological conditions, other applications have also been developed. In particular, $\mathrm{pH}$ changes can be reconstructed effectively (Mitchell et al. 2001). Testate amoebae can also be used to assess the ecological impact of some specific events such as the deposition of volcanic ash on peatlands (Dwyer 
and Mitchell 1997). A range of new applications has thus been emerging over the past 10 years and others are being reinvigorated by renewed interest. A number of examples are given here. Such new developments are very promising and may still represent only a fraction of the full potential of testate amoebae in ecological and paleoecological research.

\section{Limnology and palaeolimnology}

Studies on the ecology of lake and river testate amoebae have shown that they respond to the trophic status, $\mathrm{pH}$, and pollution (Beyens et al. 1986; Burbidge and Schröder-Adams 1998; Dalby et al. 2000; Kumar and Patterson 2000; Moraczewski 1962; Ruzicka 1982; Schönborn 1965a, 1966, 1973; Schönborn et al. 1965). Testate amoebae communities may also respond to large scale changes in land use such as deforestation and subsequent watershed management such as fertilizer and pesticide use (Patterson et al. 2002; Scott and Medioli 1983). It has also been suggested that some taxa respond directly to climate and mean temperature change (McCarthy et al. 1995). As in peatlands, the preservation of tests in many lake sediments means that subfossil testate amoebae communities can be used to trace changes in these environmental conditions over time (Ellison 1995; Ruzicka 1982; Schönborn 1973). It is important that interpretation of lacustrine assemblages take into account the diverse range of influences on testate amoebae in these environments. For example changes to more acidic indicators in a lake may reflect soil development in the catchment and transport of soil dwelling tests in run off water rather than a change in lake water conditions (Ellison 1995).

\section{Sea-level change}

Testate amoebae have been found in estuarine environments, where their range overlaps with that of foraminifera, a large group of protists much better known in the marine realm (Charman et al. 1998; Gehrels et al. 2001; Medioli et al. 1990; Scott et al. 2001). As with other habitats there are still diverse opinions on the taxonomy of this particular group of testate amoebae but it is clear that in marginal coastal settings there is a strong zonation of testate amoebae assemblages. This has been shown in a number of locations in the UK (Charman et al. 2002), and North America, where the testate data are normally considered along with foraminifera (e.g., Scott et al. 2001). Earlier studies tended only to examine larger taxa found in the same size range as foraminifera $(>63 \mu \mathrm{m})$ but more recent studies have demonstrated that a much greater abundance and diversity of taxa can be found when a smaller size range is included (Charman et al. 1998).

In a similar approach to that used for peatland water tables (see above), multivariate statistical methods can also be applied to the sea-level data to provide estimates of individual taxon optima and their ability to predict mean sea-level elevation (Fig. 5). By comparison with other bio-indicators of sea level, testate amoebae are particularly abundant and show strongest zonation in the upper parts of saltmarshes. In these situations, they have the potential to produce much more precise estimates of sea-level elevation than groups such as foraminifera and diatoms. Combining groups together may provide an optimum approach to reconstruction of former sea levels from saltmarsh sediments (Gehrels et al. 2001). Use can also be made of testate amoebae in understanding the rates of transition from saline lagoon to freshwater lake environments in isolation basins where sea level has fallen. As with saltmarsh sediments, extending the range of size fractions analysed yields a much richer assemblage of tests (Lloyd 2000; Roe et al. 2002). 


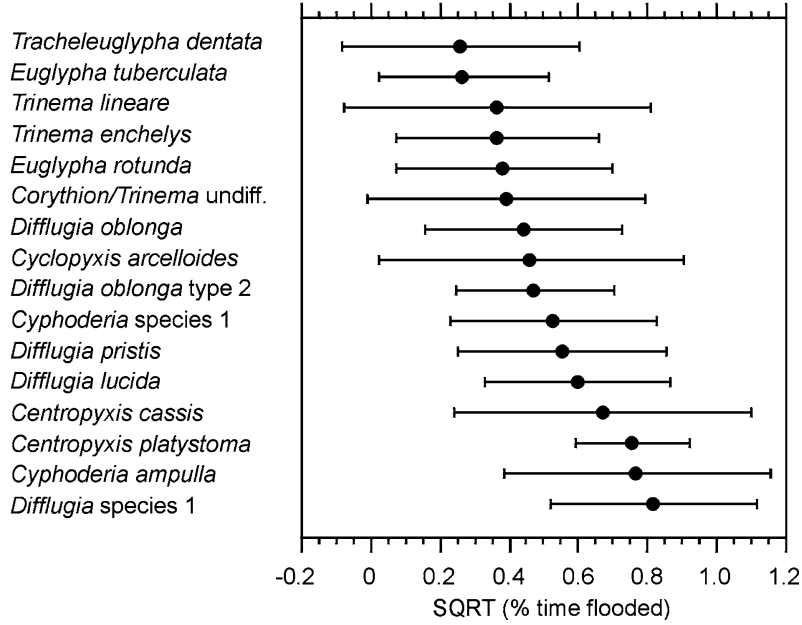

Fig. 5 Optimum position in the tidal frame of testate amoebae in British saltmarshes. The circles show the optimum and the bars the tolerance of each taxon. Data are plotted as the \% of time (square root) that a location is flooded by the tide over an annual cycle. i.e., lower values are higher up the saltmarsh and subject to less flooding. See Gehrels et al. (2001) for details. Reproduced with permission of the Quaternary Research Association

While all the modern studies confirm that elevation in relation to mean sea level is by far the most important determinant of assemblage composition in coastal environments, it is clear that other factors may also play a significant role. Elevation is a proxy for period of tidal inundation, which creates differences in hydrological and salinity conditions across a saltmarsh. However, salinity may vary independently from elevation (for example in relation to micromorphology of a saltmarsh) and other factors such as particle size and organic content of the substrate probably also play a role (Charman et al. 2002).

To date, most of the work on coastal testate amoebae has focused on contemporary ecology. The ultimate aim of much of the work is to apply it in palaeo-reconstructions. Initial assessments of the abundance of fossil tests in a variety of coastal sediments suggests preservation of tests may be quite variable and that capitalising on this potential application will need careful site selection (Roe et al. 2002). Certainly conditions in coastal settings are more physically dynamic and geochemically variable than those found in acid peatlands and lakes, and this probably explains why finding well-preserved tests is still a challenging prospect.

\section{Paleoclimatology}

Testate amoebae are now being used as indicators of paleoclimate in ombrotrophic peatlands only indirectly, through their response to hydrological changes. Their usefulness as a paleoecological tool would be much greater if one could show that they also respond directly to temperature changes. Such a response is suggested by patterns of testate amoebae diversity in relation to latitude. Indeed, testate amoeba diversity decreases with increasing latitude: \pm 300 taxa in the Arctic (Beyens and Chardez 1995) from a total of \pm 2000 , and a decline in nebelid (Nebela species and closely related taxa) species richness were observed towards high southern latitudes (Smith 1992, 1996; Wilkinson 1994). But are these trends real or are they rather due to lower available and therefore sampled habitat diversity? 
Fig. 6 Testate amoeba diagram showing the vertical distribution, as relative proportions, of testate amoebae in a peat monolith from Le Cachot, a cutover bog in the Swiss Jura Mountains. Zone designations are: L, living Sphagnum mosses; S, secondary peat; D\&O, detrital and old cutover horizon; DC, highly decomposed catotelm peat; CA, catotelm peat. See Buttler et al. (1996) for details. Reproduced with permission of the New Phytologist

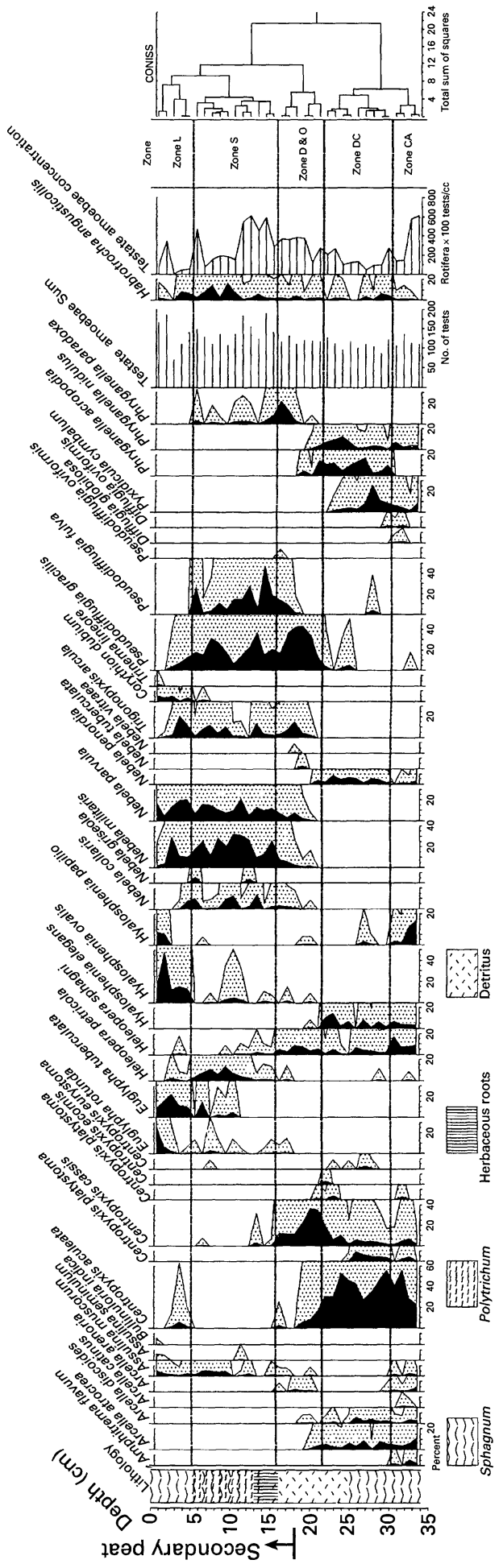


The main difficulty to address the possible influence of temperature on testate amoebae is to take into account the confounding effects of factors such as water table, $\mathrm{pH}$, and host plants. Indeed, plant communities and soil types are generally strongly correlated to latitudinal and altitudinal gradient (Odum 1971). It is not surprising that micro-organisms living in soil or mosses also respond strongly to this gradient if they are analysed in the different habitats (soil type or moss species) found along a climatic gradient, as has usually been the case (Loranger et al. 2001; Todorov 1998).

One way to avoid confounding factors is to limit the study to a very specific habitat such as one moss species. To date the only study in which a standard substrate was used (a single moss species, Hylocomium splendens, sampled in similar situations along three altitudinal gradients) has failed to demonstrate a significant overall reduction in diversity with increasing altitude (Mitchell et al. 2004). Such a result suggests that testate amoebae may not respond very clearly to temperature, at least not in terms of overall diversity. Further studies are needed, perhaps in different regions or habitats. To properly address this issue requires (1) a well-defined sampling protocol to explore the natural patterns, and (2) an experimental approach to test the effect of temperature alone on the amoebae.

\section{Peatland regeneration and management monitoring}

Much of this review concerns applications of testate amoebae analysis to palaeoenvironmental reconstructions and interpretation of past conditions. Some of these cover the recent past (i.e., less than 300 years) (Buttler et al. 1996; Hendon and Charman 2004; Patterson et al. 2002; Reinhardt et al. 2001). However, there is a growing recognition that testate amoebae can also be used in shorter-term biomonitoring. For example, testate amoebae are starting to be used in the monitoring of peatland regeneration (Davis and Wilkinson 2004; Jauhiainen 2002; Laggoun-Défarge et al. 2004), and peatland management (McMullen et al. 2004; Vickery and Charman 2004) (Fig. 6).

In wetlands, the small scale variability of testate amoebae assemblages may make representative repeat sampling difficult (Mitchell et al. 2000a) and careful sampling strategies are needed to reliably identify statistically significant differences over time or between management treatments. Experiments need to include adequate replication to account for spatial variability. Vickery and Charman (2004) compared testate amoebae populations in experimental plots following different forestry harvest and hydrological management on a Scottish raised bog. The overall health of testate amoebae communities was assessed by the percentage of living tests present. Improved conditions were created by leaving some tree remains on the bog rather than clearing away all remnants of harvested trees, and this probably reflects a mulching effect, which keeps the moisture content of surface moss higher than in open conditions.

The response of testate amoebae to soil moisture rather than water table depth suggests that major vegetation change on the mire surface may affect palaeohydrological reconstructions independently of climate change. Such changes are only likely to arise from major human disturbance or severe fire, which would generally be visible in the pollen or plant macrofossil record.

\section{Soil and air pollution monitoring}

Given the sensitivity of testate amoebae to water chemistry and other micro-environmental gradients, it is not very surprising that several studies have illustrated how they respond to soil pollution (Kandeler et al. 1992; Wanner and Dunger 2001, 2002), and to atmospheric pollution (Balik 1991; Nguyen-Viet et al. 2004). These studies showed that the diversity 
and in some cases the density of testate amoebae was lower in polluted situations. As was observed in lake studies, some species seem to tolerate higher pollution levels than others and may even be found only in the polluted sites (Nguyen-Viet et al. 2007). The exact reason why some species are more tolerant than others remains to be determined. Very little is known about the exact mechanisms by which water chemistry influences testate amoebae.

This response of testate amoebae to pollution could make them very valuable as integrative monitors of pollution. Indeed one major challenge of pollution monitoring is the spatial and temporal variability of the pollution. To accurately describe the pollution, and hence to take appropriate actions to limit its impact on the health of Humans and the environment, it is necessary to have continuous or very regular measurements. This approach, combined with the observation of living organisms, constitutes the optimal approach. This may be an option in developed countries, but is not in many poor regions. In such cases, a biomonitoring approach, either alone or combined with a lower resolution sampling for chemical analyses, could constitute a viable low-cost alternative.

\section{Other possible fields of study or applications}

The reasons that testate amoebae offer so much potential for biomonitoring applications are similar to those listed for palaeoenvironmental applications; the speed of response to change is of the order of days to weeks, and the diversity of the fauna is high. A unique characteristic of testate amoebae (as compared with ciliates or nematodes for example) is the preservation of the tests of dead individuals, at least over short periods of time (months to years) in soils. This means that living and dead assemblages could be used to provide information on very short-term or long-term conditions respectively. Some comparative studies suggest that testate amoebae respond more dramatically than ciliates to the conversion of a soil to agriculture, by a reduction in species richness of up to 50\% as compared with neighbouring natural soils (Foissner 1997b).

We believe that we are only seeing a fraction of the potential applications of testate amoeba analysis as an ecological tool. As examples of some unusual application (albeit far from the general topic of this review), testate amoebae have been shown to be reliable indicators of the truffle-bearing potential of soils in the South of France (Bonnet 1977, 1979) and were also used in a murder case: by analysing the testate amoebae found in the mud on the shoes of a suspect, it could be proven that he had been present at the murder scene (Lambert and Chardez 1978)!

\section{Concluding remarks}

Testate amoebae are clearly an interesting group of bioindicator organisms in peatland ecology and paleoecology. Like any method, this one currently suffers from some limitations. Some of these are certainly inherent to the organisms themselves but others are due to current limitations in the knowledge we have on their taxonomy, ecology and biogeography. The current interest and research effort in these organisms will no-doubt increase their reliability and also extent the range of possible applications in the future.

Acknowledgements Edward Mitchell is supported by Swiss NSF project $\mathrm{n}^{\circ} 205321-109709 / 1$ and was supported by EU project RECIPE, partly funded by the European Commission ( ${ }^{\circ}$ EVK2-2002-00269) and partly, for the Swiss partners, by the State Secretariat for Education and Research, Switzerland. SEM illustrations were produced at the SEM lab of the University of Alaska Anchorage under the direction of Dr. Jerry Kudenov. Jan Pawlowski of the University of Geneva provided critical comments on parts of the manuscript. The critical comments of two anonymous reviewers on the manuscript are gratefully acknowledged. 


\section{References}

Balik V (1991) The effect of the road traffic pollution on the communities of testate amoebae (Rhizopoda, Testacea) in Warsaw (Poland). Acta Protozool 30:5-11

Beyens L, Chardez D (1987) Evidence from testate amoebae for changes in some local hydrological conditions between c. 5000 BP and c. 3800 BP on Edgeøya (Svalbard). Polar Res 5:165-169

Beyens L, Chardez D (1995) An annotated list of testate amoebae observed in the Arctic between the longitudes 27 degrees E and 168 degrees W. Arch Protistenkd 146:219-233

Beyens L, Chardez D, Delandtsheer R, Debaere D (1986) Testate amoebae communities from aquatic habitats in the Arctic. Polar Biol 6:197-205

Blundell A, Barber K (2005) A 2800-year palaeoclimatic record from Tore Hill Moss, Strathspey, Scotland: the need for a multi-proxy approach to peat-based climate reconstructions. Quatern Sci Rev 24:12611277

Bobrov AA, Charman DJ, Warner BG (1999) Ecology of testate amoebae (Protozoa: Rhizopoda) on peatlands in western Russia with special attention to niche separation in closely related taxa. Protist 150:125-136

Bobrov AA, Mazei Y (2004) Morphological variability of testate amoebae (Rhizopoda: Testacealobosea: Testaceafilosea) in natural populations. Acta Protozool 43:133-146

Boeuf O, Gilbert D (1997) Presence of testate amoebae (genus:Trinema), in the Upper Pliocene, discovered in the locality of Chilhac (Haute-Loire, France). Comptes rendus de l'academie des sciences Série II Fascicule a- Sciences de la Terre et des planetes 325:623-627

Bonnet L (1958) Les thécamoebiens des Bouillouses. Bulletin de la Société d'Histoire Naturelle de Toulouse 93:529-543

Bonnet L (1977) Thécamoebiens et potentialités truffières des sols. In: Communication de la 16ème Réunion du Groupement des Protistologues de Langue Française, 21 pp

Bonnet L (1979) Thécamoebiens Rhizopoda Testacea et potentialités truffières des sols. Nouvelles données. Mushroom Sci 10:1013-1038

Booth RK (2001) Ecology of testate amoebae (Protozoa) in two lake superior coastal wetlands: implications for paleoecology and environmental monitoring. Wetlands 21:564-576

Booth RK (2002) Testate amoebae as paleoindicators of surface-moisture changes on Michigan peatlands: modern ecology and hydrological calibration. J Paleolimnol 28:329-348

Booth RK, Jackson ST (2003) A high resolution record of late-Holocene moisture variability from a Michigan raised bog, USA. The Holocene 13:863-876

Booth RK, Jackson ST, Gray CED (2004) Paleoecology and high-resolution paleohydrology of a kettle peatland in upper Michigan. Quatern Res 61:1-13

Bovee EC (1985) Class Lobosea Carpenter, 1861. In: Lee JJ, Hutner SH, Bovee EC (eds) An illustrated guide to the protozoa. Allen University Press, Lawrence, Kansas, pp 158-211

Burbidge SM, Schröder-Adams CJ (1998) Thecamoebians in Lake Winnipeg: a tool for Holocene paleolimnology. J Paleolimnol 19:309-328

Buttler A, Warner BG, Grosvernier P, Matthey Y (1996) Vertical patterns of testate amoebae (Protozoa: Rhizopoda) and peat forming vegetation on cutover bogs in the Jura, Switzerland. New Phytologist 134:371-382

Caseldine C, Gearey B (2005) A multiproxy approach to reconstructing surface wetness changes and prehistoric bog bursts in a raised mire system at Derryville Bog, Co. Tipperary, Ireland. The Holocene 15:585

Cash J, Wailes H (1915) The British Freshwater Rhizopoda and Heliozoa Ray Society, London

Cavalier-Smith T, Chao EE (1997) Sarcomonad ribosomal RNA sequences, rhizopod phylogeny, and the origin of euglyphid amoebae. Arch Protistenkd 147:227-236

Chacharonis P (1954) Observations on the ecology of protozoa associated with Sphagnum. Dissertation, Ohio State University

Chacharonis P (1956) Observations on the ecology of protozoa associated with Sphagnum. J Protozool 3:11

Chardez D (1969) Le genre Phryganella Penard (Protozoa, Rhizopoda, Testacea). Bulletin de la Station de Recherche Agronomique de Gembloux 4:315-322

Chardez D (1989) On the multiplication of Centropyxis discoides and the medium influence on the morphology of the test (Rhizopoda Testacea). Acta Protozool 28:31-34

Chardez D (1991) The Genus Cyphoderia Schlumberger, 1845 (Protozoa, Rhizopoda, Testacea). Acta Protozool 30:49-53

Charman DJ (1997) Modelling hydrological relationships of testate amoebae (Protozoa: Rhizopoda) on New Zealand peatlands. J Royal Soc NZ 27:465-483

Charman DJ (2001) Biostratigraphic and palaeoenvironmental applications of testate amoebae. Quatern Sci Rev 20:1753-1764 
Charman DJ, Brown AD, Hendon D, Karofeld E (2004) Testing the relationship between Holocene peatland palaeoclimate reconstructions and instrumental data at two European sites. Quatern Sci Rev 23:137-143

Charman DJ, Caseldine C, Baker A, Gearey B, Hatton J, Proctor C (2001) Paleohydrological records from peat profiles and speleothems in Sutherland, northwest Scotland. Quatern Res 55:223-234

Charman DJ, Hendon D (2000) Long-term changes in soil water tables over the past 4500 years: relationships with climate and North Atlantic atmospheric circulation and sea surface temperature. Clim Change 47:45-59

Charman DJ, Hendon D, Packman S (1999) Multiproxy surface wetness records from replicate cores on an ombrotrophic mire: implications for Holocene palaeoclimate records. J Quatern Sci 14:451-463

Charman DJ, Hendon D, Woodland WA (2000) The identification of testate amoebae (Protozoa: Rhizopoda) in peats Quaternary Research Association, London

Charman DJ, Roe HM, Gehrels WR (1998) The use of testate amoebae in studies of sea-level change: a case study from the Taf Estuary, south Wales, UK. The Holocene 8:209-218

Charman DJ, Roe HM, Gehrels WR (2002) Modern distribution of saltmarsh testate amoebae: regional variability of zonation and response to environmental variables. J Quatern Sci 17:387-409

Charman DJ, Warner BG (1992) Relationship between testate amoebae (Protozoa, Rhizopoda) and microenvironmental parameters on a forested peatland in Northeastern Ontario. Can J Zool-Revue Canadienne De Zoologie 70:2474-2482

Charman DJ, Warner BG (1997) The ecology of testate amoebae (Protozoa: Rhizopoda) in oceanic peatlands in Newfoundland, Canada: modelling hydrological relationships for palaeoenvironmental reconstruction. Ecoscience 4:555-562

Chiverrell RC (2001) A proxy record of late Holocene climate change from May Moss, northeast England. J Quatern Sci 16:9-29

Clarholm M (1981) Protozoan grazing of bacteria in soil - Impact and importance. Microb Ecol 7:343-350

Clarholm M (1985) Interactions of bacteria, protozoa and plants leading to mineralization of soil nitrogen. Soil Biol Biochem 17:181-187

Clarholm M (2002) Bacteria and protozoa as integral components of the forest ecosystem - their role in creating a naturally varied fertility. Antonie van Leeuwenhoek J Microbiol 81:309-318

Clarhom M, Rosswall T (1980) Biomass and turnover of bacteria in a peat forest soil and a peat. Soil Biol Biochem 12:49-57

Corbet SA (1973) An illustrated introduction to the testate rhizopods in Sphagnum, with special reference to the area around Malham Tarn, Yorkshire. Field Studies 3:801-838

Coûteaux M-M, Pussard M (1983) Nature du régime alimentaire des protozoaires du sol. In: LeBrun P, André HM, De Medts A, Grégoire-Wibo C, Wauthy G (eds) new trends in soil biology, proceedings of the VIII. International colloquium of soil biology, Louvain-la-Neuve (Belgium). pp 179-195

Dalby AP, Kumar A, Moore JM, Patterson RT (2000) Preliminary survey of arcellaceans (thecamoebians) as limnological indicators in tropical Lake Sentani, Irian Jaya, Indonesia. J Foraminiferal Res 30:135-142

Darling KF, Kucera M, Pudsey CJ, Wade CM (2004) Molecular evidence links cryptic diversification in polar planktonic protists to Quaternary climate dynamics. Proc Nat Acad Sci USA 101:7657-7662

Darling KF, Wade CM, Stewart IA, Kroon D, Dingle R, Brown AJL (2000) Molecular evidence for genetic mixing of Arctic and Antarctic subpolar populations of planktonic foraminfers. Nature 405:43-47

Davis SR, Wilkinson DM (2004) The conservation management value of testate amoebae as 'restoration' indicators: speculations based on two damaged raised mires in northwest England. The Holocene $14: 135-143$

Deflandre G (1928) Le genre Arcella Ehrenberg. Morphologie-Biologie. Essai phylogénétique et systématiqe. Arch Protistenkd 64:152-287

Deflandre G (1929) Le genre Centropyxis Stein. Arch Protistenkd 67:322-375

Deflandre G (1936) Etude monographique sur le genre Nebela Leidy. Ann Protistol 5:201-286

Dwyer RB, Mitchell FJG (1997) Investigation of the environmental impact of remote volcanic activity on North Mayo, Ireland, during the mid-Holocene. The Holocene 7:113-118

Earle LR (2000) The development of an unusual peat-accumulating bofedal ecosystem in the Chilean Altiplano. M.Sc. thesis, University of Waterloo

Ellison RL (1995) Paleolimnological analysis of ullswater using testate amebas. J Paleolimnol 13:51-63

Finlay BJ (2002) Global dispersal of free-living microbial eukaryote species. Science 296:1061-1063

Finlay BJ, Clarke KJ (1999) Ubiquitous dispersal of microbial species. Nature 400:828

Finlay BJ, Esteban GF, Clarke KJ, Olmo JL (2001) Biodiversity of terrestrial protozoa appears homogeneous across local and global spatial scales. Protist 152:355-366

Finlay BJ, Esteban GF, Olmo JL, Tyler PA (1999) Global distribution of free-living microbial species. Ecography 22:138-144 
Finlay BJ, Fenchel T (1999) Global Diversity and body size. Answer to Siemann, Tilmann and Haarstad 1999. Nature 383:132-133

Foissner W (1997a) Global soil ciliate (Protozoa, Ciliophora) diversity: A probability-based approach using large sample collections from Africa, Australia and Antartica. Biodivers Conserv 6:1627-1638

Foissner W (1997b) Protozoa as bioindicators in agroecosystems, with emphasis on farming practices, biocides, and biodiversity. Agric Ecosyst Environ 62:93-103

Foissner W (1998) An updated compilation of world soil ciliates (Protozoa, Ciliophora), with ecological notes, new records, and descriptions of new species. Eur J Protistol 34:195-235

Foissner W (1999) Protist diversity: estimates of the near-imponderable. Protist 150:363-368

Foissner W, Korganova GA (1995) Redescription of 3 testate amebas (Protozoa, Rhizopoda) from a caucasian soil-centropyxis plagiostoma Bonnet and Thomas, cyclopyxis kahli (Deflandre) and cyclopyxis intermedia kufferath. Arch Protistenkd 146:13-28

Foissner W, Korganova GA (2000) The Centropyxis aerophila complex (Protozoa: Testacea). Acta Protozool 39:257-273

Foissner W, Schiller W (2001) Stable for 15 million years: scanning electron microscope investigation of Miocene euglyphid thecamoebians from Germany, with description of the new genus Scutiglypha. Eur J Protistol 37:167-180

Gehrels WR, Roe HM, Charman DJ (2001) Foraminifera, testate amoebae and diatoms as sea-level indicators in UK saltmarshes: a quantitative multiproxy approach. J Quatern Sci 16:201-220

Gilbert D, Amblard C, Bourdier G, Francez A-J (1998a) The microbial loop at the surface of a peatland: structure, function, and impact of nutrient input. Microb Ecol 35:83-93

Gilbert D, Amblard C, Bourdier G, Francez A-J, Mitchell EAD (2000) Le régime alimentaire des thécamoebiens. Annee Biol 39:57-68

Gilbert D, Amblard C, Bourdier G, Francez AJ (1998b) Short-term effect of nitrogen enrichment on the microbial communities of a peatland. Hydrobiologia 374:111-119

Grospietsch T (1958) Wechseltierchen (Rhizopoden) Kosmos Verlag, Stuttgart

Grospietsch T (1964) Monographische Studie der Gattung Hyalosphenia Stein. Hydrobiologia 26:211-241

Harnisch O (1925) Studien zur Ökologie und Tiergeographie der Moore. Zoologisch Jahrbuch (Abteilung Systematik) 51:1-166

Harnisch O (1927) Einige Daten zur recenten und fossilen testaceen Rhizopodenfauna der Sphagnen. Arch Hydrobiol 18:345-360

Harnisch O (1958) II. Klasse: Wurzelfüssler, Rhizopoda. In: Brohmer P, Ehrmann P, Ulmer G (eds) Die Tierwelt Mitteleuropas, Band 1: Urtiere-Hohltiere-Würmer, Lieferung 1b. Quelle \& Meier, Leipzig, pp 1-75

Hausmann K, Hülsmann N, Radek R (2003) Protistology, 3rd completely revised edition edn. E. Schweizerbart'sche Verlagsbuuchhandlung, Berlin, Stuttgart

Hayward BW, Holzmann M, Grenfell HR, Pawlowski J, Triggs CM (2004) Morphological distinction of molecular types in Ammonia-towards a taxonomic revision of the world's most commonly misidentified foraminifera. Mar Micropaleontol 50:237-271

Heal OW (1961) The distribution of testate amoebae (Rhizopoda: Testacea) in some fens and mires in northern England. Zool J Linn Soc 44:369-382

Heal OW (1962) The abundance and microdistribution of testate amoebae (Protozoa: Rhizopoda) in Sphagnum. Oikos 13:35-47

Heal OW (1964) Observations on the seasonal and spatial distribution of testaceans (Protozoa: Rhizopoda) in Sphagnum. J Anim Ecol 33:395-412

Hendon D, Charman DJ (2004) High-resolution peatland water-table changes for the past 200 years: the influence of climate and implications for management. The Holocene 14:125-134

Hendon D, Charman DJ, Kent M (2001) Palaeohydrological records derived from testate amoebae analysis from peatlands in northern England: within-site variability, between-site comparability and palaeoclimatic implications. The Holocene 11:127-148

Jauhiainen S (2002) Testacean amoebae in different types of mire following drainage and subsequent restoration. Eur J Protistol 38:59-72

Jung W (1936) Thekamöben ursprünglischer lebender deutscher Hochmoore. Abhandlung Landesmuseum der Provinz Westfalen 7:1-87

Kandeler E, Luftenegger G, Schwarz S (1992) Soil microbial processes and testacea (Protozoa) as indicators of heavy-metal pollution. Zeitschrift Fur Pflanzenernahrung Und Bodenkunde 155:319-322

Kumar A, Patterson RT (2000) Arcellaceans (thecamoebians): new tools for monitoring long- and short-term changes in lake bottom acidity. Environ Geol 39:689-697

Laggoun-Défarge F, Mitchell EAD, Gilbert D, Warner BG, Comont L, Disnar J-R, Buttler A (2004) Biochemical characteristics of peat organic matter and distribution of testate amoebae in two naturally 
regenerating cutover Sphagnum peatlands of the Jura mountains. In: Proceedings of the 12th International Peat Congress, Vol. 1, pp 383-384, Tampere, Finland

Lambert J, Chardez D (1978) Intérêt criminalistique de la microfaune terrestre. Revue Internationale de Police criminelle 319:158-170

Lamentowicz M, Mitchell EAD (2005) The ecology of testate amoebae (Protists) in Sphagnum in north-west Poland in relation to peatland ecology. Microb Ecol 39:290-300

Langdon PG, Barber KE, Hughes PDM (2003) A 7500-year peat-based palaeoclimatic reconstruction and evidence for an 1100-year cyclicity in bog surface wetness from Temple Hill Moss, Pentland Hills, southeast Scotland. Quatern Sci Rev 22:259-274

Lavoie M, Richard PJH (2000) The role of climate on the developmental history of Frontenac Peatland, southern Quebec. Can J Bot-Revue Canadienne de Botanique 78:668-684

Lee JJ, Leedale GF, Bradbury P (eds) (2000) An illustrated guide to the Protozoa, 2nd edn. Lawrence, Kansas, pp 1432

Lloyd J (2000) Combined foraminiferal and thecamoebian environmental reconstruction from an isolation basin in NW Scotland: Implications for sea-level studies. J Foraminiferal Res 30:294-305

Loeblich AR, Tappan H (1964) Sarcodina. Chiefly "thecamoebians" and foraminiferida. In: Moore RC (ed) Treatise on invertebrate paleontology C(2), vol. 1. Geological Society of America and University of Kansas Press, Lawrence, Kansas, pp C2-C54

Loranger G, Bandyopadhyaya I, Razaka B, Ponge JF (2001) Does soil acidity explain altitudinal sequences in collembolan communities? Soil Biol Biochem 33:381-393

Lussenhop J, Treonis A, Curtis PS, Teeri JA, Vogel CS (1998) Response of soil biota to elevated atmospheric $\mathrm{CO}_{2}$ in poplar model systems. Oecologia 113:247-251

Lüftenegger G, Petz W, Berger H, Foissner W, Adam H (1988) Morphologic and biometric characterization of 24 soil Testate Amebas (Protozoa, Rhizopoda). Arch Protistenkd 136:153-189

Mauquoy D, Barber K (1999) Evidence for climatic deteriorations associated with the decline of Sphagnum imbricatum Hornsch ex Russ. in six ombrotrophic mires from northern England and the Scottish Borders. The Holocene 9:423-437

Mauquoy D, Barber K (2002) Testing the sensitivity of the palaeoclimatic signal from ombrotrophic peat bogs in northern England and the Scottish Borders. Rev Palaeobot Palynol 119:219-240

McCarthy FMG, Collins ES, McAndrews JH, Kerr HA, Scott DB, Medioli FS (1995) A comparison of postglacial Arcellacean (Thecamoebian) and pollen succession in Atlantic Canada, illustrating the potential of Arcellaceans for paleoclimatic reconstruction. J Paleontol 69:980-993

McGlone MS, Wilmshurst JM (1999) A Holocene record of climate, vegetation change and peat bog development, east Otago, South Island, New Zealand. J Quatern Sci 14:239-254

McMullen JA, Barber KE, Johnson B (2004) A paleoecological perspective of vegetation succession on raised bog microforms. Ecol Monograp 74:45-77

Medioli FS, Scott DB, Collins ES, McCarthy FMG (1990) Fossil thecamoebians: present status and prospects for the future. In: Hemleben C, Kaminski MA, Kuhnt W, Scott DB (eds) Proceedings of the NATO advanced study institute on paleoecology, biostratigraphy, paleoceanography and taxonomy of agglutinated foraminifera, vol. 327, D. Reidel Publishing Company, Dordrecht-Boston, International, pp 813-839

Meisterfeld R (1977) Die horizontale und vertikale Verteilung der Testaceen (Rhizopoda: Testacea) in Sphagnum. Arch Hydrobiolo 79:319-356

Meisterfeld R (1978) Die Struktur von Testaceenzönosen (Rhizopoda, Testacea) in Sphagnum unter besonderer Berücksichtigung ihrer Diversität. Verhandlungen der Gesellschaft für Ökologie 7:441-450

Meisterfeld R (1979) Cluster-Analysis of Associations of Testate Ameba (Rhizopoda, Testacea) in Sphagnum. Arch Protistenkd 121:270-307

Meisterfeld R (2002a) Order Arcellinida Kent, 1880. In: Lee JJ, Leedale GF, Bradbury P (eds) The illustrated guide to the protozoa, vol. 2, Society of protozoologists, Lawrence, Kansas, USA, pp 827-860

Meisterfeld R (2002b) Testate amoebae with filopodia. In: Lee JJ, Leedale GF, Bradbury P (eds) The illustrated guide to the protozoa, vol. 2. Society of protozoologists, Lawrence, Kansas, USA, pp 1054-1084

Mignot JP, Raikov IB (1992) Evidence for meiosis in the Testate Ameba Arcella. J Protozool 39:287-289

Mitchell EAD (2004) Response of testate amoebae (Protozoa) to N and P fertilization in an Arctic wet sedge tundra. Arct Antarct Alp Res 36:77-82

Mitchell EAD, Borcard D, Buttler AJ, Grosvernier P, Gilbert D, Gobat JM (2000a) Horizontal distribution patterns of testate amoebae (Protozoa) in a Sphagnum magellanicum carpet. Microb Ecol 39:290-300

Mitchell EAD, Bragazza L, Gerdol R (2004) Testate Amoebae (Protista) Communities In Hylocomium splendens (Hedw.) B.S.G. (Bryophyta): relationships with altitude, and moss elemental chemistry. Protist $155: 423-436$ 
Mitchell EAD, Buttler A, Grosvernier P, Rydin H, Albinsson C, Greenup AL, Heijmans MMPD, Hoosbeek MR, Saarinen T (2000b) Relationships among testate amoebae (Protozoa), vegetation and water chemistry in five Sphagnum-dominated peatlands in Europe. New Phytologist 145:95-106

Mitchell EAD, Buttler AJ, Warner BG, Gobat JM (1999) Ecology of testate amoebae (Protozoa: Rhizopoda) in Sphagnum peatlands in the Jura mountains, Switzerland and France. Ecoscience 6:565-576

Mitchell EAD, Gilbert D (2004) Vertical micro-distribution and response to nitrogen deposition of Testate amoebae in Sphagnum. J Eukaryot Microbiol 51:485-495

Mitchell EAD, Gilbert D, Buttler A, Grosvernier P, Amblard C, Gobat J-M (2003) Structure of microbial communities in Sphagnum peatlands and effect of atmospheric carbon dioxide enrichment. Microb Ecol 46:187-199

Mitchell EAD, Meisterfeld R (2005) Taxonomic confusion blurs the debate on cosmopolitanism versus local endemism of free-living protists. Protist 156:263-267

Mitchell EAD, van der Knaap WO, van Leeuwen JFN, Buttler A, Warner BG, Gobat JM (2001) The palaeoecological history of the Praz-Rodet bog (Swiss Jura) based on pollen, plant macrofossils and testate amoebae (Protozoa). The Holocene 11:65-80

Moraczewski J (1962) Differenciation ecologique de la faune des Testacés du littoral peu profond du lac Mamry. Pol Arch Hydrobiol 10:334-353

Nguyen-Viet H, Bernard N, Mitchell EAD, Cortet J, Badot P-M, Gilbert D (2007) Relationship between testate amoebae and atmospheric heavy metals ( $\mathrm{Pb}, \mathrm{Cd}, \mathrm{Zn}, \mathrm{Ni}, \mathrm{Cu}, \mathrm{Mn}$ and $\mathrm{Fe}$ ) accumulated in the moss Barbula indica Hanoi, Vietnam. Microb Ecol 53:53-65

Nguyen-Viet H, Gilbert D, Bernard N, Mitchell EAD, Badot P-M (2004) Relationship between atmospheric pollution characterized by $\mathrm{NO}_{2}$ concentrations and testate amoebae abundance and diversity. Acta Protozool 43:233-239

Nikolaev SI, Mitchell EAD, Petrov NB, Berney C, Fahrni J, Pawlowski J (2005) The testate lobose amoebae (order Arcellinida Kent, 1880) finally find their home within Amoebozoa. Protist 156:191-202

Odum EP (1971) Fundamentals of ecology, 3rd edn. W. B. Saunders Co., Philadelphia

Ogden CG (1983) Observations on the systematics of the genus Difflugia in Britain (Rhizopoda, Protozoa). Bull Nat Hist Mus Zool 44:1-73

Ogden CG, Hedley RH (1980) An atlas to freshwater testate amoebae. Oxford University Press, Oxford

Patterson DJ (1996) Free-living freshwater Protozoa: a colour guide. Manson Publishing Ltd., London

Patterson RT, Dalby A, Kumar A, Henderson LA, Boudreau REA (2002) Arcellaceans (thecamoebians) as indicators of land-use change: Settlement history of the Swan Lake area, Ontario as a case study. J Paleolimnol 28:297-316

Patterson RT, Kumar A (2002) A review of current testate rhizopod (thecamoebian) research in Canada. Palaeogeograp Palaeoclimatol Palaeoecol 180:225-251

Penard E (1902) Les Rhizopodes du bassin du Léman Kündig, Genève

Porter SM, Knoll AH (2000) Testate amoebae in the Neoproterozoic Era: Evidence from vase- shaped microfossils in the Chuar Group, Grand Canyon. Paleobiology 26:360-385

Primeau S (2004) Coastal freshwater wetland development in Mexico: A 4,500 -year record of succession from Laguna La Mancha, Vera Cruz. M.Sc. Thesis, University of Waterloo

Quinn NP (2003) Testate amoebae (Protozoa) assemblages as environmental indicators of water tables and soil moisture in a kettle hole peatland in southern Ontario. M.Sc. Thesis, University of Waterloo

Reinhardt EG, Dalby A, Kumar A, Patterson RT (2001) Utility of arcellacean morphotypic variants as pollution indicators in mine tailing contaminated lakes near Cobalt, Ontario, Canada. Micropaleontology 47:95-95

Roe HM, Charman DJ, Gehrels WR (2002) Fossil testate amoebae in coastal deposits in the UK: implications for studies of sea-level change. J Quatern Sci 17:411-429

Ruzicka E (1982) Die subfossile Testaceen des Krottensees (Salzburg, Oesterreich). Limnologica (Berlin) $1: 49-88$

Schmidt AR, von Eynatten H, Wagreich M (2001) The Mesozoic amber of Schliersee (southern Germany) is Cretaceous in age. Cretaceous Res 22:423-428

Schreve DC, Thomas GN (2001) Critical issues in European quaternary biostratigraphy. Quatern Sci Rev 20:1577-1582

Schönborn W (1962) Zur Ökologie der sphagnicolen, bryokolen un terrikolen Testaceen. Limnologica 1:231254

Schönborn W (1963) Die Stratigraphie lebender Testaceen im Sphagnetum der Hochmoore. Limnologica $1: 315-321$

Schönborn W (1965a) Die Sedimentbewohnenden Testaceen einiger Masurischer Seen. Acta Protozool 3:297-309

Schönborn W (1965b) Studien über die Gattung Difflugiella (Rhizopoda, Testacea). Limnologica 3:315-328 
Schönborn W (1966) Testaceen als Bioindikatoren im System der Seetypen Untersuchungen in Masurischen Seen und im Suwaki-Gebiet (Polen). Limnologica 4:1-11

Schönborn W (1973) Paleolimnological studies of Testacea from Lake-Latnjajaure (Abisko-Region-Swedish-Lapland). Hydrobiologia 42:63-75

Schönborn W (1992a) Adaptive polymorphism in soil-inhabiting testate amoebae (Rhizopoda): its importance for delimitation and evolution of asexual species. Arch Protistenkd 142:139-155

Schönborn W (1992b) The role of protozoan communities in freshwater and soil ecosystems. Acta Protozool 31:11-18

Schönborn W, Dorfelt H, Foissner W, Krienitz L, Schafer U (1999) A fossilized microcenosis in Triassic amber. J Eukary Microb 46:571-584

Schönborn W, Flossner D, Proft G (1965) Die Limnologische Characterisirung des Profundals einiger Seen mit Hilfe von Testaceen-Geimenschaften. Limnologica 3:371-380

Schönborn W, Foissner W, Meisterfeld R (1983) Light and SEM studies of the shell morphology and formation of races in soil-living Testacea-Proposals of a biometrical characterization of Testacea shells. Protistologica 19:553-566

Scott DB, Medioli FS (1983) Agglutinated rhizopods in Lake Erie: modern distribution and stratigraphic implications. J Paleontol 57:809-820

Scott DB, Medioli FS, Schafer CT (2001) Monitoring in coastial environments using foraminifera and thecoamoebian indicators. Cambridge Unversity Press, Cambridge

Smith HG (1992) Distribution and ecology of the testate rhizopod fauna of the continental Antarctic zone. Polar Biol 12:629-634

Smith HG (1996) Diversity of Antarctic terrestrial protozoa. Biodivers Conserv 5:1379-1394

Todorov M (1998) Observation on the soil and moss testate amoebae (Protozoa: Rhizopoda) from Pirin Mountain (Bulgaria). Acta Zool Bulgarica 50:19-29

Tolonen K (1986) Rhizopod analysis. In: Berglund BE (ed) Handbook of holocene palaeoecology and palaeohydrology. John Wiley and Sons, Chichester, pp 645-666

Tolonen K, Warner BG, Vasander H (1992) Ecology of testaceans (Protozoa, Rhizopoda) in mires in Southern Finland.1. Autecology. Arch Protistenkd 142:119-138

Tolonen K, Warner BG, Vasander H (1994) Ecology of Testaceans (Protozoa, Rhizopoda) in Mires in Southern Finland.2. Multivariate-Analysis.Arch Protistenkd 144:97-112

Treonis AM, Lussenhop JF (1997) Rapid response of soil protozoa to elevated $\mathrm{CO}_{2}$. Biol Fertil Soils 25:60-62

Van Oye P (1944) Au sujet de la distribution géographique des Rhizopodes. Biologisch Jaarboek 11:83-91

Vickery E, Charman DJ (2004) Biomonitoring of peatland restoration using testate amoebae. In: Verhoeven JTA, Dorland E, Coemans M (eds) 7th INTECOL international wetlands conference, vol. Book of abstracts, Utrecht, NL, 25-30 July 2004, pp 342

Wanner M (1999) A review on the variability of testate amoebae: Methodological approaches, environmental influences and taxonomical implications. Acta Protozool 38:15-29

Wanner M, Dunger W (2001) Biological activity of soils from reclaimed open-cast coal mining areas in Upper Lusatia using testate amoebae (protists) as indicators. Ecol Eng 17:323-330

Wanner M, Dunger W (2002) Primary immigration and succession of soil organisms on reclaimed opencast coal mining areas in eastern Germany. Eur J Soil Biol 38:137-143

Wanner M, Esser S, Meisterfeld R (1994) Effects of light, temperature, fertilizers and pesticides on growth of the common freshwater and soil species Cyclopyxis Kahli (Rhizopoda, Testacealobosia), interactions and adaptations. Limnologica 24:239-250

Wanner M, Meisterfeld R (1994) Effects of some environmental factors on the shell morphology of testate amoebae (Rhizopoda, Protozoa). Eur J Protistol 30:191-195

Warner BG (1987) Abundance and diversity of testate amoebae (Rhizopoda, Testacea) in Sphagnum peatlands in Southwestern Ontario, Canada. Arch Protistenkd 133:173-189

Warner BG (1990) Testate Amoebae (Protozoa). In: Warner BG (ed) methods in Quaternary ecology, vol. Reprint Series 5. Geoscience Canada, St. John's, Newfoundland, pp 65-74

Warner BG, Asada T, Quinn NP (2007) Seasonal influences on the ecology of testate amoebae (Protozoa) in a small Sphagnum peatlands in southern Ontario, Canada. Microb Ecol 54:91-100

Warner BG, Charman DJ (1994) Holocene changes on a Peatland in Northwestern Ontario interpreted from Testate Amebas (Protozoa) analysis. Boreas 23:270-279

Warner BG, Chmielewski JG (1992) Testate amoebae (Protozoa) as indicators of drainage in a forested mire, northern Ontario, Canada. Arch Protistenkd 141:179-183

Wilkinson DM (1994) A review of the biogeography of the protozoan genus Nebela in the southern temperate and Antarctic zones. Area 26:150-157

Wilkinson DM (2001) What is the upper size limit for cosmopolitan distribution in free-living microorganisms? J Biogeograp 28:285-291 
Wilmshurst JM, McGlone MS, Charman DJ (2002) Holocene vegetation and climate change in southern New Zealand: linkages between forest composition and quantitative surface moisture reconstructions from an ombrogenous bog. J Quatern Sci 17:653-666

Woodland WA, Charman DJ, Sims PC (1998) Quantitative estimates of water tables and soil moisture in Holocene peatlands from testate amoebae. The Holocene 8:261-273

Wylezich C, Meisterfeld R, Meisterfeld S, Schlegel M (2002) Phylogenetic analyses of small subunit ribosomal RNA coding regions reveal a monophyletic lineage of euglyphid testate amoebae (order Euglyphida). J Eukary Microbiol 49:108-118 